\title{
The Global Regulation of "Fake News" in the Time of Oxymora: Facts and Fictions about the Covid-19 Pandemic as Coincidences or Predictive Programming?
}

\author{
Rostam J. Neuwirth ${ }^{1}$ (D)
}

Accepted: 31 March 2021 / Published online: 13 April 2021

(c) The Author(s), under exclusive licence to Springer Nature B.V. 2021

\begin{abstract}
The beginning of the twenty-first century saw an apparent change in language in public discourses characterised by the rise of so-called "essentially oxymoronic concepts", i.e., mainly oxymora and paradoxes. In earlier times, these rhetorical figures of speech were largely reserved for the domain of literature, the arts or mysticism. Today, however, many new technologies and other innovations are contributing to their rise also in the domains of science and of law. Particularly in law, their inherent contradictory quality of combining apparently antagonistic suppositions challenges the traditional dualistic mode of reasoning and binary logic. As reflected in terms like fake news, alternative facts or conspiracy theories, these concepts are seen as a threat to the rule of law and legal certainty and have been described as harbingers of an age of disinformation or post-truth. The challenge posed by these apparently contradictory concepts requires a closer look at the premises that guide our legal thinking and a more integrated theory of the senses and their role in law, as captured by the terms "legal synaesthesia" and "legal semiotics". It also calls for an inquiry into the mind's functioning generally and how it processes information in the creative process of decision making, linking thoughts and actions as well as facts and fictions. Based on the qualification of "fake news" as an oxymoron, this article critically examines the deficiencies in a dichotomous distinction between fact and fiction exemplified by information about the pandemic of coronavirus disease 2019 (Covid-19) in an attempt to clarify the principal issues for a global regulatory debate regarding "fake news".
\end{abstract}

Keywords Essentially oxymoronic concepts · Oxymora · Legal Synaesthesia · Fake news $\cdot$ International law $\cdot$ Self-Fulfilling/-defeating prophecy

Rostam J. Neuwirth

rjn@um.edu.mo

1 Department of Global Legal Studies, Faculty of Law, University of Macau, Avenida da Universidade, Macao SAR 999078, China 


\section{Introduction}

Language is a virus from outer space [16].

The concept "fake news" is now a frequently invoked concepts in public regulatory debates. It shares this privilege with related concepts like "alternative facts", "social media", "artificial intelligence", "virtual reality", or "conspiracy theory". It is by no means a coincidence that each of these, and many more concepts, has been described and qualified as an essentially oxymoronic concept [86]. This category of concepts evolved from Walter B. Gallie's notion of "essentially contested concepts" [35] and comprises, notably, oxymora, contradictiones in adiecto or paradoxes, all of which are rhetorical figures of speech expressing varying degrees of contradictions ranging from a single to two or more words [83, p. 150]. The frequency of the usage of these concepts confirms earlier predictions about the twenty-first century being the age of paradox [45, p. x], or an era characterised by the difficulties in discerning "powerful tensions, profound contradictions, and perplexing paradoxes" [107, p. 13].

Do the many oxymora and paradoxes constitute a new kind of post-truth rhetoric? [72, pp. 7-9] Does the frequency of such contradictions mean we have entered the disinformation age, meaning that is a time of great volatility where deception, misrepresentation, outright dishonesty, as well as incomplete information, inadequate reporting, and biased or otherwise egregiously faulty analyses remain as the few constants $[108$, p. 82]?

While the use of paradoxes and oxymora in literature, the arts and even mysticism was common, it is their recent rise in significance in the fields of science and of law that raises important questions about what constitutes objective reality or truth as the foundations for scientific and legal certainty. The reason is that their inherent contradictions caused by the juxtaposition of antagonistic concepts, like "wise" and "folly" or "true" and "false", in one word or sentence, is likely to confuse the reader and to render a conclusive judgment in terms of dualistic thinking and binary logic impossible.

Thus the legal equivalent of the twenty-first century as the age of paradox has been described by the book "Law in the Time of Oxymora" published in 2018, which connotes a world, in which "the complexity and the accelerated pace of change equally threaten-like a new pandemic global disease-to undermine law, especially the rule of law as an instrument providing legal certainty and predictability" [84, p. xiii]. In other words, law in the time of oxymora means to ask if today, contrary to the traditionally dualistic reasoning applied in law, it is now opportune to hold that a person is guilty and innocent, a contract valid and void, an act legal and illegal at the same time [20, p. 4]. Applied to the case of information, it means to conclude that news can be "true" and "fake" at the same time [66]. Such result of legal reasoning, however, would have serious repercussions on the current debates in many jurisdictions around the world about the possible regulation or prohibition of "fake news" [33]. 
To avoid such confusion, it is necessary to remember the complex and cross-sectional nature of "fake news", which, as Lili Levi notes, means that no single or simple tactic can or should "address the variety of challenges posed by the multi-headed phenomenon of "fake news", the reason being that "the issue of the relationship between the press, the government, and the public is so profoundly important and difficult; because 'fake news' is such a multi-faceted and evolving phenomenon; and because today's information environment is so complicated, proposing remedies to address the problem requires great care and restraint" [66, p. 237].

Against this backdrop, the paper will first provide an overview of the current international regulatory situation and future debate regarding "fake news" and related concepts (Sect. 2). It will also critically highlight that the present international legal framework is marginal at best and that various national efforts to regulate fake news are-due to the global information technology revolution manifest in the creation of cyberspace-ill-fated as well. Subsequently, it will address deeper conceptual and cognitive problems related to a possible legal qualification of "fake news" as an oxymoron (Sect. 3). This discussion focuses on the linguistic as well as cognitive confusion caused by these concepts and the role of the perception of time in the assessment of information being fake (false) or true. It then explores the phenomenon of "predictive programming," which is a concept used to describe various products of the entertainment industry as a tool to control the minds of masses with the aim to prepare them for planned future policies and events (Sect. 4). By listing examples of predictive programming in the context of the coronavirus disease 2019 (Covid-19) pandemic, the paper aims to gain insights not only into the deeper premises that guide our legal thinking but also the wider links between the world of law and the world of fiction. The similarity between fictitious and factual accounts of the pandemic suggests to query for a new paradigm for future regulatory debates, one that may build on a new cognitive mind-set enabling a new understanding about law and the future itself (Sect. 5). Finally, the paper draws some short-term conclusions about elements and different legal areas that should be considered in future debates about the regulation of "fake news" and, more importantly, about a global legal framework guaranteeing the free flow of news and other information (Sect. 6).

\section{The Age of Paradox or "Fake News" as a Glocal Phenomenon}

\section{Mankind, in coming of age, has begun to be subject to the necessity and to feel} the urgency of forming one single body coextensive with itself [23, p. 15].

Perhaps surprising to many, the term "fake news" is not as new or as alien to international regulatory debates as it seems. The intentional use of misinformation is a serious concern that has existed for a long time and was used as a technique for many harmful purposes including the incitement to wage wars [97]. It has gained new attention, notably in the context of the interference with elections [63], Brexit [106], and, most recently, during the Covid-19 global pandemic, also characterised as a "global misinfodemic" [110], whereby misinformation was said to spread faster than the virus itself. In this respect, the spread of the global pandemic and of fake 
news both confirm the characterisation of the present time as paradoxical, which David Held characterised as follows:

The paradox of our times can be stated simply: the collective issues we must grapple with are increasingly global and, yet, the means for addressing these are national and local, weak and incomplete [49, p. 143].

To briefly recall, it was on March 11, 2020 that the World Health Organization (WHO) declared the Corona Virus Disease (Covid-19) a pandemic, which means an epidemic of an infectious disease that has spread across multiple continents or worldwide. The responses formulated since then, however, were primarily taken and implemented at the national or even local levels [125]. By contrast, calls for concerted actions taken at the global level are widely absent or were merely expressions of intent that nonetheless remained unheard [34].

This situation is similar to the regulatory actions taken to halt the dissemination of fake news, which are almost exclusively implemented at the national level, such as in Singapore, ${ }^{1}$ Germany, ${ }^{2}$ or France, ${ }^{3}$ even though modern communication and information technologies are borderless and operate globally. In short, there are currently many more national debates ongoing but no plan for a future global regulatory strategy aiming to contain the problem of misinformation can be found [33].

In order to find some international responses, one has to go back in history. The only existing international legal instruments directly applicable to fake news are marginal, incomplete and fragmented at best. As will be shown below, they are widely obsolete, which may be of no surprise given that these historical documents are the League of Nations' Convention on the 1936 International Convention on the Use of Broadcasting in the Cause of Peace, ${ }^{4}$ and the UN General Assembly's 1953 Convention on the International Right of Correction. ${ }^{5}$

The first instrument, the 1936 Broadcasting Convention, thus takes a pessimistic view on the new information technology of broadcasting as it warns of its potential threats to international peace. In this regard, it is interesting to add that it was originally prepared by the League of Nations' International Committee for Intellectual Cooperation (ICIC) in parallel to the 1933 Convention for Facilitating the International Circulation of Films of an Educational Character, which had taken a more optimistic view. ${ }^{6}$ The optimism was expressed in its Preamble,

\footnotetext{
1 Protection from Online Falsehoods and Manipulation Act (POFMA), Republic of Singapore Government Gazette No. 28 (28 June 2019); available at: https://sso.agc.gov.sg/Acts-Supp/18-2019.

2 "Network Enforcement Act" (Netzwerkdurchsetzungsgesetz vom 1. September 2017 (BGB1. I S. 3352); available at: https://www.gesetze-im-internet.de/netzdg/BJNR335210017.html.

3 “Law Against Information Manipulation”, LOI n 2018-1202 du 22 décembre 2018 relative à la lutte contre la manipulation de l'information; JORF n ${ }^{\circ} 0297$ du 23 décembre 2018; available at: https://www. legifrance.gouv.fr/download/pdf?id=6-nJtAIQpD8-Ugn4wumM7mxoCtqh9SJ32VBSCt4dzzI=

4 International Convention on the Use of Broadcasting in the Cause of Peace 1936, 186 LNTS 301 [Broadcasting Convention].

${ }^{5}$ Convention on the International Right of Correction, New York, 31 March 1953, 435 UNTS 191 [Correction Convention].

${ }^{6}$ Convention for Facilitating the International Circulation of Films of an Educational Character, signed at Geneva, October 11, 1933, 1 L.N.T.S. 333 [Circulation Convention].
} 
which mentions the desire "to facilitate the international circulation of educational films of every kind, which contribute towards the mutual understanding of peoples". Yet, while advocating the free trade of educational content, the Circulation Convention also recognizes the High Contracting Parties' right "to censor films in accordance with their own laws or to adopt measures to prohibit or to limit the importation or transit of films for reasons of public security or order" (Art. VIII).

By contrast, the 1936 Broadcasting Convention obliges the High Contracting Parties to prohibit or delay "the broadcasting within their respective territories of any transmission which to the detriment of good international understanding is of such a character as to incite the population of any territory to acts incompatible with the internal order or the security of a territory of a high contracting party" (Art. 1). It also obliges them to ensure that "transmissions from stations within their respective territories shall not constitute an incitement either to war against another High Contracting Party or to acts likely to lead thereto" (Art. 2). Most importantly, the said convention also obliges parties to prohibit any transmission "likely to harm good international understanding by statements the incorrectness of which is or ought to be known to the persons responsible for the broadcast" (Art. 3). This last article is the most relevant and comes closest to a general prohibition of fake news in international law. Plus, the said convention offers procedures to verify the false information and even an international procedure for the settlement of disputes including the International Court of Justice (ICJ), arbitration and other methods of dispute resolution.

As for the second international legal instrument, the 1953 Correction Convention prepared by the UN General Assembly is even more explicit in this regard, as the contracting states recognize in the Preamble "the right of their peoples to be fully and reliably informed" and desire "to improve understanding between their peoples through the free flow of information and opinion" as well as "to protect mankind from the scourge of war, to prevent the recurrence of aggression from any source, and to combat all propaganda". Last, and important for any future regulatory strategy at the global level, it is also interesting to note the Convention's consideration that, at the time, it was considered impracticable to institute a procedure at the international level for verifying the accuracy of a report which might lead to the imposition of penalties for the publication of false or distorted reports. Nonetheless, what constitutes perhaps the most important contribution of the Correction Convention is the procedure it lays out for the verification and correction of inaccurate or distorted news reports (Art. II).

When discussing the possible regulation of fake news, it is also important to consider the existing international legal framework guaranteeing the free flow of information and related rights. For instance, the Universal Declaration of Human Rights lists several fundamental rights that stand in stark opposition to restrictions of the free flow of information, such as the right to freedom of thought, conscience and religion, and the freedom of opinion and expression, which includes the freedom "to 
seek, receive and impart information and ideas through any media and regardless of frontiers".?

However, the complexity of drawing the line between freedom of information and useful restrictions thereof, is reflected in the text of the later International Covenant of Political and Civil Rights (ICCPR). ${ }^{8}$ In Article 19, the ICCPR restates the right of everyone to hold opinions without interference and to freedom of expression. The latter right has been specified to include the "freedom to seek, receive and impart information and ideas of all kinds, regardless of frontiers, either orally, in writing or in print, in the form of art, or through any other media of his choice". Such wide interpretation of the said freedom, however, is limited by Article 20 ICCPR, which states that "any propaganda for war" as well as "any advocacy of national, racial or religious hatred that constitutes incitement to discrimination, hostility or violence" shall be prohibited by law. It is also noteworthy that the International Covenant on Economic, Social and Cultural Rights (ICESCR) extends these freedoms to the kind of information deemed indispensable for scientific research and creative activity. ${ }^{9}$

This brief overview of existing international legal instruments relevant for the problem of fake news shows, first and foremost, the severity of the problem of the fragmentation of international law. It also reflects, likely as a result of the widespread traditional use of dualistic thinking, the tendency of the members of the international community to address a single coherent problem by way of separating it into two opposite constituents, by usually framing it using dichotomies. This is the case with broadcasting, where the positive (educational) effects were separated from the negative (harmful) effects, as exemplified by the 1933 and 1936 Conventions. A similar tendency can be observed in the case of intellectual property rights, where the artistic or cultural aspects were separated from their commercial aspects through the 1883 Paris Convention and the 1886 Berne Convention respectively. ${ }^{10}$ The same tendency repeated itself in the treatment of cultural products under the aegis of the World Trade Organization (WTO), which, by way of Articles IV and XX of the 1947 General Agreement on Tariffs and Trade (GATT) as well as Articles XIV and XVI of the General Agreement on Trade in Services (GATS), widely exempts them from the rules of the liberalization of international trade [82]. Finally, it was despite the so-called "indivisibility of human rights" that the political and civil aspects of fundamental rights were separated from their social, economic and cultural counterparts by means of the two 1966 International Covenants mentioned before. This problem and the balance of different rights is also manifest in the context of the current pandemic

\footnotetext{
7 Article 18 and 19 Universal Declaration of Human Rights (UDHR), GA Res. 217 (III), UN GAOR, 3d Sess., Supp. No. 13, UN Doc. A/810 (1948).

8 International Covenant on Civil and Political Rights, adopted by the General Assembly of the United Nations on December 16, 1966, 999 U.N.T.S. 171.

9 Article 15 International Covenant on Economic, Social and Cultural Rights, adopted by the General Assembly of the United Nations on December 16, 1966, 993 U.N.T.S. 3.

10 Paris Convention for the Protection of Industrial Property of March 20, 1883, 828 U.N.T.S. 306 and the Berne Convention for the Protection of Literary and Artistic Works of September 9, 1886, 828 U.N.T.S. 221.
} 
with the problem of finding the right balance between individual rights and liberties and their restrictions due to public health during pandemics [91, 100].

The problem with the formulation of such regulatory approaches using dualistic thinking is that they trade accuracy for simplicity. However, life and the reality surrounding it is regularly more complex and certainly more paradoxical. Akin to the paradoxes of freedom and of tolerance mentioned by Karl Popper [96, pp. 109 $\&$ 226], the paradox of the regulation of fake news could thus be described by the dilemma of how much restriction to the free flow of information is permissible in order to guarantee the free flow of information in the first place. Related to this paradox is the oxymoron of "glocalisation" [111, p. 3], which, when applied to digital media, translates into the fact that fake news technically operates at the global level while it is legally addressed locally, as summarized by the paradox formulated by David Held above.

This glocal paradox also confirms that a so-called "international regulatory approach" to fake news, as it was undertaken in the past, is unfit to contain the problem today. The reason is that today's fake news is not mostly false reports circulated by national media outlets from one state into another. The problem is truly global or transnational, as the news now includes stakeholders made of public and private, local and global, as well as individual and collective entities. As it was stated, fake news is made up of a mixture of such reports, plus governments setting up "teams, made of public officials, volunteers, fake accounts, and bots - a software application that runs automated tasks over the internet to interact with and mimic human users - or a mix of those to manage and influence public opinion online", as well as individual users disseminating information via blog posts, YouTube videos, fake news stories or manipulated images to mention but a few [2, p. 1]. In short, the international conventions cited above also show how outdated the concept of international law already is, by almost exclusively relying on national sovereignty and a territorial conception, which-it seems-is clearly technically, economically and socially, but, unfortunately, not politically outdated.

In view of such complexity, it is important to recall the wider purposes that paradoxes and contradictions serve. Among these purposes is the function to remind us that their occurrence often represents instances where current knowledge may be deficient, which renders predictions based on such knowledge inconsistent with actual events or findings [57, p. 1]. Moreover, oxymoronic expressions show that framing problems as dichotomies based on dualistic thinking and binary logic alone is inadequate and outdated, not only for the sensory framework of perception, but also the purpose of regulation [84, pp. 245-6]. For instance, in the case of new technologies, related regulatory approaches in the sole form of prohibitions or recommendations, were found to be insufficient [27, pp. 156-7].

For this reason, it is necessary to seek more comprehensive regulatory approaches at the global level beyond mere state intervention. Moreover, as an encounter with profound contradictions, paradoxes and oxymora alike also force us "to search for the deeper causes of the legal premises that guide our thinking" [30, p. 1292]. To this end, it is deemed useful to briefly inquire into the meaning of the term "fake news" but from a global perspective. 


\section{3 "Fake News" as an Oxymoron: Law between Fact and Fiction}

Just like a map that can never correspond entirely to the territory it represents, information can never correspond to reality in every detail [6, p. 1372].

When it comes to the search for a definition of the term "fake news", it soon becomes clear that there exists no single definition or broad consensus, as the phenomenon itself seems too broad and complex at the same time [117, p. 137]. It is nonetheless useful to mark the distinction made between "fake news" and "distorted news". The former is defined as news items that are intentionally fabricated, regardless of their author's ultimate intention, while the latter are more subtle forms of information trying to influence or manipulate people's beliefs and behaviour [6, pp. 1358-9]. In addition to this broad distinction, there exists a plethora of definitions matching the different perspectives by those formulating them, which include international organizations, public authorities or broadcasters, scholars and private social media platforms, such as Facebook or YouTube [2, p. 2]. Generally, however, a globally accepted single, let alone legal authentic definition is to date non-existent.

In view of such plethora of definitions of fake news, one can either essentially contest the different meanings in endless disputes [35, p. 169], or have recourse to essentially oxymoronic language. The latter approach leads to "fake news" being qualified as an oxymoron, because "[N]ews is supposedly-and normatively-based on truth, which makes the term 'fake news' an oxymoron" [117, p. 140]. Another publication comes to a similar conclusion when it states that the term fake news is an oxymoron because " "news' means verifiable information in the public interest, and information that does not meet these standards does not deserve the label of news" [54, p. 7].

The repeated qualification of fake news and many more terms of public interest underscores the observed trend to move from the use of essentially contested concepts towards essentially oxymoronic concepts [84, pp. 6-24]. This trend also underscores the intrinsic connection that exists between these various phenomena, as many more related terms, such as "social media" [129, p. 210], "artificial intelligence" [37, p. 99], or "virtual reality" [127, p. 330] have all been qualified as oxymora and are but a few examples of a wider trend.

As language is one of the means through which the law acts, the apparent rise in the number of oxymora and paradoxes in scientific and legal discourses must be taken seriously, as it has wider repercussions for the future of law in general and different areas of law in particular. Some of these implications for law in general, and for international customary law, comparative law or international adjudication have been outlined in several individual publications [84-86]. For the present context of fake news, it important to stress that the changes in language indicate a deeper change happening, possibly indicating a cognitive revolution requiring a deeper inquiry into the links between language, logic and the senses. This query also confirms the need for more interdisciplinary approaches to law, such as between law and neuroscience [93], and a renewed interest in the "law and literature" movement 
or novel concepts like "legal synaesthesia" [84, pp. 234-43] or "synaesthetic legalities" $[8,70]$ as well as "legal semiotics" [126].

The concept of legal synaesthesia is derived from the merger of law and synaesthesia. Synaesthesia means "to sense together" and describes "a condition in which one sensory modality also gives rise to a sensation in a different modality" [104, p. 3]. It was also defined as the parallel sensation of two or more, or all, of the senses $[22$, p. 1). It is important for law not only because we all might be born with synaesthesia already [25] but it may also be the rule rather than the exception in the future of perception [77, p. 229]. Thus, legal synaesthesia can be understood to describe the close interplay between law, perception and all the senses and argues-in line with legal semiotics-for a more inclusive focus on all senses instead of just one, as both law and perception are in a constant search for greater coherence as a means to avoid the negative effects of both the fragmentation of the senses and of the law [124, pp. 159-181, 53].

Semiotics, as the science of signs which can be communicated through all the senses [47, p. 110], therefore marks an important point of departure for the debate about fake news in relation to new technologies. To give but two examples, a wider sensory spectrum allows for dissolving confusion between the senses, as captured by the McGurk effect, which describes the perceptual phenomenon that the mind may overrule what we hear based on what we see [73]. The same effect also helps to explain why it is harder to communicate with wearing the Covid-19 face masks, because we cannot detect lip movements or other facial expressions [79]. Secondly, reliance on a wider sensory spectrum may also prove useful in the exposure of so-called "deep fakes" [135]. Deep fakes usually describe AI-generated fake face images or videos, which lift the problem of misinformation through fake news to even higher levels. In this regard, it would be interesting to see further research studying various human abilities, such as intuition $[39,114$, p. 175], and particularly the role of synaesthesia in relation to the abilities of individuals to differentiate between real and fake content [43].

As for the legal response to fake news and its qualification as an oxymoron here, it is important to stress another aspect, namely the inadequacy of language to accurately describe reality and complex phenomena. This problem can be exemplified in analogy to the concept of time, as observed by Carlo Rovelli as follows:

The grammar of many modern languages conjugates verbs in the "present," "past," and "future" tense. It is not well-adapted for speaking about the real temporal structure of reality, which is more complex [109, p. 8].

It is the perception and understanding of time, which is also extremely important for the question of the solution of the conundrums described by oxymora and paradoxes [84, pp. 257-62]. One reason for this importance is that time is the prime unit applied to the measurement of change. With change apparently occurring faster, as captured by the notion of an acceleration of change [40], there is also greater uncertainty as to what is true or false or real and fake. With regard to time, it is also interesting to mention another oxymoron, i.e., the one of "old news". This term was qualified as an oxymoron by a Canadian court in a case dealing with a delay of the 
ability to report the "news" as an injury to the Freedom of the Press. ${ }^{11}$ This example highlights precisely the major problem regarding the qualification of a news report as being false, fake or truthful comes into play. We know from the history of science that many scientific theories were deemed as heresy in the present only to be later confirmed to be true [69]. The reverse is also possible that scientific facts were hailed as a major discovery only to be little later laughed at as a hoax. Unfortunately, the law has often been involved, instrumentalised or causal in such erroneous outcomes. Does this mean that there is a "fake science" and judicial error leads to law being "fake" too?

While this question must remain unanswered here, it reminds of the fact that the line between fact and fiction is often difficult to draw. This was once observed by the statement that "one by one we have seen how categories, which at first seem sharply defined, merge one into another, and how every classification, when analysed, shows that some imaginary line has been arbitrarily taken as a boundary" [67, pp. 178]. This observation brings us back to the argument that both science and law are now prone to provide scientific insights by way of paradoxes or oxymora. In the widest possible sense, this analogy between the two can be exemplified by the two concepts of "science fiction" and "legal fiction", both having been qualified as oxymora. As for science fiction, the reason given was that "[I]t invokes and delivers dichotomies, insoluble dilemmas, deceptive solutions. It makes manifest worlds upon worlds that are too contradictory to exist" [21, p. 8]. A legal fiction, on the other hand, was equated to "a contradictio in adjecto, a self-deception, even a declaration of bankruptcy by [legal] science!" [123, p. 7] as well as explicitly qualified as an oxymoron in a court case. ${ }^{12}$

Both qualifications do not mean that fact cannot be discerned from fiction within a given context and a fixed set of criteria. However, they can also not be taken to mean that all scientific truths will hold their validity at all places and at all times. To the contrary, the intrinsic connection between law and science in this regard has also been established by a paradox, namely the one of scientific authority, which holds that "the cases in which scientific advice is asked most urgently are those in which the authority of science is questioned most thoroughly" [11, p. 1].

It is likely for the reason of this paradoxical scientific uncertainty that the law itself has used the instrument of legal fiction since early history [1]. One of the most common definitions of legal fiction is that is an assumption that something is true about something that is known to be false [32, p. 393]. It can also be described as an imaginary structure in law used to fulfil a higher purpose of the law, such as to correct inadequacies and deficiencies in the law in force. Against this background, it appears at a first look paradoxical to try to regulate fake news by virtue of instruments which apply fictions. On the other hand, we must acknowledge that most of what we call the reality we live by, is actually made of legal and other fictions, such as state, a constitution, a corporation or money to mention but a few. It is perhaps

11 Alberta Court of Queen's Bench, R. v. Trang (D.) et al., ABQB 437 (2001) at para 72.

12 Supreme Court of Arkansas, Springdale Board of Education v. Bowman, 294 Ark. 66 (1987) at 74. 
no coincidence that the author of a book using the double oxymoronic title "Homo Deus: A Brief History of Tomorrow" qualifies the role of fictions as follows:

In the twenty-first century fiction might thereby become the most potent force on earth, surpassing even wayward asteroids and natural selection. Hence if we want to understand our future, cracking genomes and crunching numbers is hardly enough. We must also decipher the fictions that give meaning to the world [46, p. 152].

The importance of fictions was also recognized for law by the need to rethink legal thinking as indicated by the debate about fake news. This need was captured by the term "jurisfiction", which was described as follows:

The recent fashion to loudly debate "fake news" and "fake facts" and permit "fact checking" as a "fake control" is a clear sign. It tells us that traditional legal hermeneutics, the art of interpreting and architecting legal facts, is no longer a single means to articulate law's diction. That consideration leads the rethinking of legal thoughts towards a different background-an attitude articulated in the word “jurisfiction' [14, pp. 1 and 43].

Again, to decipher legal and other fictions, paradoxes and oxymora are a useful reminder for the inadequacy of the current language and knowledge. They also reiterate the need to take a wider spectrum of the problem into account if an efficient solution is to be found. Therefore, and notably against the panoply of legal measures taken in response to the global pandemic so far [125], it is important to proceed from the assumption that language, the senses, the perception of time, and the distinction between fact and fiction are intricately connected. Especially, oxymoronic concepts may have a role in expanding our understanding of time and space, as expressed in the oxymoronic notion of "space-time" or the paradoxical question of why we remember the past but not the future. Reminiscent of this possible causal connection, the discussion shall next turn to the case of various factual and fictitious accounts and explanations of the current Covid-19 global pandemic.

\section{Conspiracy Theories and Predictive Programming}

There are some scholars who argue that the phrase conspiracy theory is an oxymoron [113, p. 31].

First, it is necessary to state that the outbreak of the coronavirus disease (Covid-19) not only led to a "misinfodemic" [110], but also numerous speculations branded as conspiracy theory beliefs [80]. Conspiracy theory beliefs were found to centre largely on the origin and cause of the virus (bats, 5G or laboratory, an effective treatment, and the benefits of and reasons for a Covid vaccine $[9,55]$. In this regard, it is interesting to note that there is often a substantive disagreement in the scientific community, especially when it comes to novel problems and phenomena, which invites speculation into the debate. Some of these 
speculations are branded as conspiracy theories in pejorative terms, possibly to silence opposite views and criticisms.

Another source for conspiracy theory beliefs are fictitious stories told in different media that precede their actual occurrence. For example, most people have heard or seen a movie about the Titanic, the ocean liner that tragically sank on 15 April 1912, after colliding with an iceberg on its transatlantic crossing from Southampton to New York City. Few people, however, are aware of a novella entitled "The Wreck of the Titan: Or Futility", which tells the fictitious story of a steamship called Titan, which was considered practically unsinkable but later had "hurled itself at an iceberg" and sank [105, p. 2 and 26]. This fictitious story, however, was first published in 1898, which is 14 years before the real tragic accident involving the Titanic happened.

Such events, where fiction precedes fact, are frequent. They often give rise to speculation and attempts to scientifically explain them, as coincidences, for instance. However, even coincidences may have different causes, such as hidden (or unknown) causes, psychology, a multiplicity of endpoints, or the law of truly large numbers [26, p. 853]. These explanations do not exclude the possibility, as indicated by the analogy to antitrust issues, the existence of a conspiracy, i.e., a secret and active pursuit of certain illegal goals. Despite the pejorative use of the term, it was Cass Sunstein who noted that "some conspiracy theories have, of course, turned out to be true" [115, p. 4]. This is a rather weak statement for a law professor, because from the perspective of law, any crime was, before the perpetrator(s) was (were) found, arrested and convicted by a fair trial, rightfully subject to inquiries and speculations, which could have been denoted as a conspiracy theory.

Obviously, any of such crimes can also have been committed purely based on imitation. This has been explained by the behavioural process known as so-called "copycat crimes", which has also been linked to the influence of the media [116, p. 251, 19]. This effect, however, does not preclude instances where the influence by the media exercised is not purely coincidental. The term often used to describe this form of mind control is "predictive programming", which is usually attributed to conspiracy theorists and refers to a practice "whereby the mass media are used to indoctrinate the public to future social or technological changes" [65, p. 57,71, p. 155]. If such mind control is exercised deliberately and uses different channels including facts and fiction, it can help to turn-akin to the dynamics of a self-fulfilling prophecy-a (conspiracy) theory into reality.

The prevalence of a self-fulfilling prophecy, for instance, has been found in the context of Samuel B. Huntington's theory of a "clash of civilisations" [52]. A self-fulfilling prophecy is a psychological phenomenon of someone making a prediction and then acting upon it to make it happen [10, p. 765]. In the reverse case, it is called a self-defeating prophecy. It is interesting to note that it was also defined as "a false definition of the situation evoking a new behavior which makes the originally false conception come true" [78, p. 195]. This psychological power to turn false information into real consequences was also described by the power of political myths in influencing people's minds as follows: 
Finally, if power is the ability to influence another person and make him or her do, or not do, what he or she otherwise would not, or would, have done, then it is clear that the most effective power is the power that can be felt without being seen. In this sense, symbolic power, defined as the power to construct a successful version of reality, permeates all the dimensions of power-political, ideological and economic, without it being possible to treat them without taking this symbolic dimension into consideration $[13, \mathrm{p}$. 330].

Again, the oxymoronic definition of fake news highlights the difficulty in drawing clear dichotomous lines between fact and fiction. In the context of predictive programming, the dichotomy lies between two events being based on coincidence or contrivance, meaning that they either had no causal relation or they were in fact linked by a deceitful plan.

This power of the mind to link the imaginary and reality is also reflected in the power of law. This power can be described by the seemingly oxymoronic term "poethics", as coined by Richard H. Weisberg, which combines the terms "poetry" and "ethics to perhaps explain the underlying link between "two major human enterprises: establishing justice and storytelling" [128, p. ix]. From this perspective, law, like literature, can use predictive programming as an initially fictitious means to silently "nudge" people into accepting and eventually complying with certain comfortable or uncomfortable truths, depending on the objectives pursued [119]. This sociopsychological power of the law, however, needs to be applied wisely and duly consider both when and how regulatory steps are taken.

For the issue of the regulation of fake news, it is therefore useful to provide a brief timeline of the different factual and fictitious accounts surrounding the Covid19 pandemic. Before that, not surprisingly, it is noteworthy that the term "conspiracy theory" has also been qualified as an oxymoron or contradiction in terms [99, p. 118]. Put simply, the two terms are contradicting, like the oxymoron "open secret", as a conspiracy entails a secret plot, whereas a theory is supposed to be publicly known and empirically verifiable. Unfortunately, the term "conspiracy theory" is usually given a pejorative meaning, one that can be used to discredit even the process of formulating any questions before their possible answers have been verified. This pejorative meaning attributed to the term has often the negative effect of halting a critical and investigative inquiry into the causes of certain events or developments. Without any formal inquiry, however, these events and often factual information surrounding them may simply be termed as coincidences, i.e., the occurrence of events apparently by chance, and never bring to light the acts of contrivance underlying the events. This is noteworthy as, even in the scientific realm, it was noted that "a prediction may be correct, but its theoretical basis may be false" [118, p. 4]. The same is certainly true for some so-called "conspiracy theories," where the general argument may be correct but the background knowledge may be based on incomplete information or seemingly irrational grounds. On the other hand, it is also known from many economic decisions that consumers, business people or policy 
makers take, that "we are not only irrational, but predictably irrational" because "our irrationality happens the same way, again and again" [4, p. xx].

In view of the above, trust, in both media and public institutions, plays an important role in addressing a rise in conspiracy theories [44]. The problem can perhaps be exemplified by an analogy to an area of law called "antitrust law," which-given that it was also qualified both as an oxymoron and paradox [5, p. 17, 12, pp. ix and 408] — seems to offer the right reference due to the double entente of the word "trust" in this context. The US Sherman Antitrust Act also uses the terms "conspiracy" for a contract in restraint of trade or commerce to be declared illegal. ${ }^{13}$ To exemplify the parallel, take a case where a person enters a supermarket and sees the same product category, such as Camembert Cheese, manufactured by separate companies, offered at the same price, such as $€ 4.99$. The same price may be a pure coincidence (possibly caused by similar costs in the manufacturing of the product). Or, it suggests the existence of a "conspiracy," which is called a "(price) cartel" in antitrust language. This opens the door to endless speculations until an investigation by antitrust authorities is opened, which-possibly after a raid of the companies' headquarters-establishes or refutes the existence of a cartel engaged in the illegal practice of price fixing.

Unfortunately, in the case of conspiracy theories centred on a large number of events, such inquiries are often not even pondered and even less initiated. The lack of independent transnational judicial authorities and the fact that every state operates secret services, which as their name suggests, often operate in the shadow of (or even beyond) the letter of the law, certainly does not help in this regard and contributes to the encyclopaedic dimension of conspiracies [88]. Their secrecy, a general lack of transparency and poor communication of official information can spur the formulation and spread of conspiracies. In this context, it is regrettable that the term "conspiracy theorist" has assumed such a pejorative meaning [24, pp. 31-2], which is one that stifles an open debate leading to an official inquiry, which would be closed by a conviction or acquittal of the alleged perpetrators.

In sum, the term conspiracy theory is both an essentially contested and oxymoronic concept. In line with the latter qualification, it is interesting to note that the lack of understanding of the term is caused, inter alia, by a too fragmented scholarly debate, unrealistic assumptions about the causality of events and a strictly binary Manichean logic breaking everything down into good or evil [7, pp. 82-3]. It is one that was found to range from silly online hoaxes to serious investigative reporting and from adversarial political critique to dangerous mutilations of ascertained knowledge but it was concluded that they "hold a legitimate, even important place within democratic discourse and must be protected" [7, pp. 82-3].

The potentially constructive role of conspiracy theories and the call for their protection as part of free speech appears similar to the one of fake news. To exemplify notably the limitations of a rigid binary reading, the term conspiracy theory can also be understood as a form of "controlled opposition," which can be defined as the use of a small amount of ridiculous or exaggerated disinformation aimed at discrediting

${ }^{13}$ Section 1 Sherman Anti-Trust Act (1890), ch. 647, 26 Stat. 210 (1890). 
a wider range of genuine information or legitimate claims. Fake news can also be instrumentalised in this regard, which leaves the interested reader of news content offered by today's mass media with an infodemic or an intellectual cocktail of mass information made of genuine news versus fake news, serious issues versus humour and satire, science versus pseudoscience, or-ultimately-fact versus fiction to mention but a few [28]. Moreover, the language used in this mass media content is often replete with oxymoronic concepts, like "alternative facts" or, what could be termed, other "doublespeak", in reminiscence to George Orwell's "Newspeak" and "doublethink" as new ways to exercise reality control [90, p. 865]. How this doublespeak, combining scientific fact and fiction as well as education and entertainment, paraphrased by the oxymora "science fiction" and "edutainment" plays out in relation to the present Covid-19 global pandemic will be shown in the next section.

\section{The Global Pandemic between Scientific Fact and Fiction}

The proper antithesis to fact is fiction, and fiction may teach a deep truth [134, p. 14].

Officially, the world became aware of the current Covid-19 virus, when it was declared a pandemic by the World Health Organization (WHO) on 11 March 2020 [133]. However, in the months and weeks before this date, news reports were growing in number reporting on a new corona virus, or strange flu cases. Even though the outbreak was initially reported from Wuhan (China), since then there have been conflicting reports regarding the origin of the virus, which - at the time of the writing - is still subject to an ongoing fact-finding mission of the WHO in Wuhan.

Soon after the WHO declaration, CNN reported a headline claiming that Dean Koontz, a writer of fiction, did not predict the coronavirus in a novel published in 1981, in response to a tweet to the contrary, which displayed a page from the novel [58]. If you have a copy of the novel from 1996, this page will read as follows:

It was around then that a Chinese scientist named Li Chen defected to the United States, carrying a diskette record of China's most important and dangerous new biological weapon in a decade. They call the stuff "Wuhan-400" because it was developed at their RDNA labs outside of the city of Wuhan, and it was the four-hundreth viable strain of man-made microorganisms created at that research center [59, p. 353].

This is certainly a striking analogy, especially that early actual news reports mentioned the outbreak of the Covid-19 in a fresh food market in Wuhan in the proximity of which is also the research lab known as the Wuhan Institute of Virology. From reading the $\mathrm{CNN}$ article, however, the reader learns that the first edition of the novel published in 1981, did not mention the term "Wuhan-400" but instead called the biological weapon "Gorki-400" after a Russian locality. According to another article, the change was introduced in the second edition in 1989 in response to the geopolitical events following the end of the Cold War [130]. 
Books, however, were not the only sources having been mentioned as prophecies or "predictive programming" in relation to the Covid-19. There are numerous motion pictures, from Twelve Monkeys (1996) to Contagion (2011), the stories of which are set around a deadly virus spreading globally. Even an episode of the Simpsons aired in 1993 was said to have predicted elements of Covid 19 [101]. Among them, the plot of Contagion is said to have come closest to the actual scenario, with a scientist dying from an unknown virus after returning from a business trip to Hong Kong and the following spread of a deadly infection.

In the context of this fictitious film, it is interesting to note that Bill Gates had delivered a Ted Talk in 2015 with the title "The Next Outbreak? We Are Not Ready", by which he meant to warn of the disastrous consequences of the next pandemic. In the talk, beginning at minute 3:09, he shows the poster of the movie Contagion and jokingly mentions the difference between "real life" and the movies, calling it "pure Hollywood" [36]. This Ted Talk is likely one of the reasons why Bill Gates' role in the Covid 19 pandemic is part of speculation and conspiracies. In this regard it does not help that he also, through the Bill and Melinda Gates Foundation, hosted together with Johns Hopkins Center for Health Security and in partnership with the World Economic Forum, the so-called "Event 201", which was a pandemic exercise held on 19 October 2019 to illustrate the preparedness for the next pandemic. ${ }^{14}$ The description of the simulated exercise reads as follows:

Event 201 simulates an outbreak of a novel zoonotic coronavirus transmitted from bats to pigs to people that eventually becomes efficiently transmissible from person to person, leading to a severe pandemic. [...].

The disease starts in pig farms in Brazil, quietly and slowly at first, but then it starts to spread more rapidly in healthcare settings. [...] It is first exported by air travel to Portugal, the United States, and China and then to many other countries. [...] There is no possibility of a vaccine being available in the first year. There is a fictional antiviral drug that can help the sick but not significantly limit spread of the disease.

Since the whole human population is susceptible, during the initial months of the pandemic, the cumulative number of cases increases exponentially, doubling every week. And as the cases and deaths accumulate, the economic and societal consequences become increasingly severe.

The scenario ends at the 18 -month point, with 65 million deaths. The pandemic is beginning to slow due to the decreasing number of susceptible people. The pandemic will continue at some rate until there is an effective vaccine or until 80-90\% of the global population has been exposed. From that point on, it is likely to be an endemic childhood disease. ${ }^{15}$

\footnotetext{
${ }^{14}$ The Johns Hopkins Center for Health Security. 2019[120,121,122]. Event 201 - A global pandemic exercise. https://www.centerforhealthsecurity.org/event201/.

15 The Johns Hopkins Center for Health Security. 2019. [120,16,86] The event 201 scenario. https:// www.centerforhealthsecurity.org/event201/scenario.html.
} 
After more than a year into the pandemic, the scenario's striking similarities to the actual developments may have prompted the organizers to publish the following statement on the website, clarifying why the Event 201 exercise did not predict the Covid 19 outbreak:

In October 2019, the Johns Hopkins Center for Health Security hosted a pandemic tabletop exercise called Event 201 with partners, the World Economic Forum and the Bill \& Melinda Gates Foundation. Recently, the Center for Health Security has received questions about whether that pandemic exercise predicted the current novel coronavirus outbreak in China. To be clear, the Center for Health Security and partners did not make a prediction during our tabletop exercise. For the scenario, we modeled a fictional coronavirus pandemic, but we explicitly stated that it was not a prediction. Instead, the exercise served to highlight preparedness and response challenges that would likely arise in a very severe pandemic. We are not now predicting that the nCoV-2019 outbreak will kill 65 million people. Although our tabletop exercise included a mock novel coronavirus, the inputs we used for modeling the potential impact of that fictional virus are not similar to nCoV-2019. ${ }^{16}$

Further speculations about the Bill Gates Foundation's involvement or potential benefits from the pandemic were spurred on by the fact that Event 201 was held on the same day that the 7th edition of the CISM Military World Games were opened. This Military sports exercise was later mentioned as a possible starting point for the dissemination of the virus in Wuhan [81, 131].

Another film is Inferno, based on Dan Brown's novel, which features the story of a billionaire who wants to depopulate the world by the use of a biological weapon, which was released in the US on 28 October $2016 .{ }^{17}$ It is a fact that the release date "coincides" with Bill Gates' birthday.

As for another coincidence of date, the 37th volume of the cartoon Asterix, with the title "Asterix and the Chariot Race" was released worldwide in more than 20 languages also on 19 October 2017, i.e., exactly two years ahead of Event 201. This is not surprising until the reader arrives at page 13, where he sees the race driver in a chariot wearing a mask (to keep anonymity) being called "Coronavirus" [42, p. 13].

These examples may be pure coincidences or were based on previously available scientific knowledge. For instance, a scientific article published in 2007 discusses the threats of coronaviruses and warns of new outbreaks based on the "presence of a large reservoir of SARS-CoV-like viruses in horseshoe bats", which it calls a time bomb leading to the "possibility of the re-emergence of SARS and other novel viruses from animals or laboratories" which requires a better preparedness" [17, p. 683]. However, science is yet undecided and the question of the origin of the Covid 19 virus is scientifically contested. It is also interesting

\footnotetext{
16 The Johns Hopkins Center for Health Security. 2019 [83,45,107] Statement about nCoV and our pandemic exercise. https://www.centerforhealthsecurity.org/news/center-news/2020/2020-01-24-Statementof-Clarification-Event201.html.

17 Internet Movie Database (IMDB). Inferno. 2016. https://www.imdb.com/title/tt3062096/.
} 
to mention another scientific publication made publicly available in March 2020, which concludes about the origin of SARS-CoV-2 that it was "not a laboratory construct or a purposefully manipulated virus" [3]. This scientific finding stands in contrast with another publication from February 2020, which reads more like the theory of the origin in a lab than in nature as it "identified 4 unique inserts in the 2019-nCoV spike glycoprotein that are not present in any other coronavirus reported till date" and suggests an "unconventional evolution of 2019-nCoV that warrants further investigation" [98]. This study, however, was withdrawn similar to another scientific publication on the use of hydroxycholorochine, once praised by the former US President, which was retracted [76].

Ultimately, the general scientific uncertainty or contestation of even scientific facts leaves the reader interested in the origin(s) of the virus, with the latest news article published in February 2021, which reports that "without doubt", the Covid 19 virus had already circulated in France in November 2019, at least one month ahead of the first report of a cluster of cases of pneumonia in Wuhan [31].

Finally, adding the legal element to the already seemingly blurred lines of distinction between science and fiction or simulation and prediction, it is useful to cite the example of the fictitious novel "The Constant Gardener" written by famous spy storywriter John LeCarré published in 2001. This book's plot is set in a corrupt context of pharmaceutical industry, which even aroused the interest of at least one member of the scientific community, who published the following comment:

Isn't it interesting that a world-renowned master spy novelist has turned his focus to the pharmaceutical companies and their relationships with the academic and health care communities to spin his yarn of intrigue? In a sense, his interest in this area is a proxy for the measurement of the seriousness of this issue. It is yet another piece of evidence of our need as academicians to rid ourselves of conflicts of interest and strive to regain this public trust [95, p. 183].

So even though "The Constant Gardener" is a work of fiction, it is taken as a real and serious concern by representatives of the relevant industry. Moreover, as for the book content's separation of reality from fiction, the usual legal disclaimer by the author is of interest, which John LeCarré has framed in the following unusual way:

In these dog days when lawyers rule the universe, I have to persist with these disclaimers, which happen to be perfectly true. With one exception nobody in this story, and no outfit or corporation, thank God, is based upon an actual person or outfit in the real world [...]. There is no Dypraxa, never was, never will be. I know of no wonder cure for TB that has recently been launched on the African market or any other-or is about to be-so with luck I shall not be spending the rest of my life in the law courts or worse, though nowadays you can never be sure. But I can tell you this. As my journey through the pharmaceutical jungle progressed, I came to realize that, by comparison with the reality, my story was as tame as a holiday postcard [62, pp. 479-80]. 
Ultimately, the content of this work may have been dubbed as fiction but was based on factual and real research. This example shows that it may be due to or for legal reasons that a legitimate concern is expressed by means of literary fiction rather than scientific research or official news. Moreover, there may be important links between the imaginary world of fiction and hard scientific research, both mutually inspiring each other.

Support for such view comes from neuroscience and the brain, where it was said that the line between a good decision and a bad decision is very thin [64, p. xiv]. It may be the same with fictitious and real content or data, as both types of information appear to constantly shape our mind. After all, even the term "raw data" was called an oxymoron [38, pp. 2-3], and it was shown that it is possible to lie also with statistics [51, pp. 8-9]. In sum, it is likely the cognitive level that will determine the future of humanity, as it was exemplified in a study aimed to depict a utopian and dystopian scenario for the future of global governance [87, 60, p. 529].

This finding is in line with how the physicist David Bohm is reported to have understood "in-formation", namely as "a message that actually 'forms' the recipient" [61, p. 2]. As both fiction and facts form our mind, they may play an important role in learning and the formation of an opinion, both individually and collectively. They are an important source for the formation of public opinion too. Perhaps in this process, the distinctions of fake or true, fictitious or real are not that far off from each other, as Nicholas Luhmann observed in the context of mass media, when he outlined how reality and fiction are associated in the consumption of media content as follows:

We do not need to go into detail here, but the question remains as to how this imaginary variety of events is linked back to external reality. It seems that knowledge which viewers already have must be referred to copiously. In this respect, entertainment has an amplifying effect in relation to knowledge that is already present. But it is not oriented towards instruction, as with news and in-depth reporting. Instead it only uses existing knowledge in order to stand out against the latter [58, 68],

In other words, acting upon a lie does always not automatically render the original lie true. No matter what the content of the fictitious idea, it will have consequences in real life, which then become facts. In this regard, it paradoxically does not matter whether the initial assumption was true or false, as-with the passing of time and actions supporting it - the initial assumption can still become true or false through acts supporting it, as it is captured by the respective terms of self-fulfilling or self-defeating prophecies.

Thus, this short survey of selected data related to the Covid-19 meant to show that scientific fact and fiction or education and entertainment are often found in close combination. This observation is best expressed by the oxymora of "science fiction" and "edutainment" but also those of "fake news" and "conspiracy theories". Therefore, the main message delivered by these and other oxymora or paradoxes is that it is no coincidence that they flourish where our understanding is deficient. This deficiency notwithstanding, the same rhetorical devices were also 
found to offer "powerful opportunities to test models and conceptual frameworks, and to enable true 'paradigm shifts' in certain areas of scientific inquiry" [57, p. 1]. It is for these and other reasons that this article concludes that the regulation of fake news should not focus on the issue of the truthfulness or falsehood of their content but the wider context instead, as will be briefly outlined in the following concluding remarks.

\section{Conclusion}

Only puny secrets need protection. Big discoveries are protected by public incredulity [74].

At the outset of the article, it was argued that public regulatory debates saw a recent rise in the frequency of the use of oxymora and paradoxes (essentially oxymoronic concepts), notably in science and in law. Following the short discussion of the current state of the debate about the regulation of fake news and their qualification as an oxymoron, the main conclusion for the future of law in general and the regulation of fake news in particular is, first and foremost, that the traditional method of framing problems through dichotomies based on dualistic thinking alone is inadequate.

For the regulation of fake news concretely, it means to refrain from their prohibition through state intervention directed at the content alone. The reason is that the message is as important as the medium [75, pp. 7-21]. As a regulatory tool, prohibitions alone have been characterised as outdated and also often mean a violation of the proportionality principle, particularly when considering the fundamental right to the "freedom to seek, receive and impart information and ideas of all kinds, regardless of frontiers, either orally, in writing or in print, in the form of art, or through any other media of his choice". 18

Regulation should also not be exclusively addressed as the biggest minority in the world, i.e., the individual. The reason is that the individual's potential harm by intentionally posting fake content is small compared to the threats by various new technological possibilities provided for the manipulation of information, propaganda or ideological polarization, such as algorithms, AI-generated deep fakes or "bots", i.e., web robots. It is better to empower individuals with the tools that allow them to detect false or misleading information and to provide them with adequate legal remedies to correct them.

Another reason is that their prohibition or oppression risks not only to curtail the rights related to the freedom of information. It would also contribute to the emergence of more distrust manifest in the circulation of conspiracy theories. The term "conspiracy theory" was also qualified as an oxymoron and should, most of all, not

\footnotetext{
18 UN Human Rights Committee, International Covenant on Civil and Political Rights, General Comment No. 34, Article 19: Freedoms of Opinion and Expression, 47, U.N. Doc CCPR/C/GC/34 (12 September 2011) at para. 34; http://www2.ohchr.org/english/bodies/hrc/docs/gc34.pdf.
} 
only be seen from a pejorative angle. It should be seen as a reminder for the need of an open, transparent and constructive debate leading to a greater collective understanding of an objective reality, which_paradoxically_is one made of the multitude of individual subjective realities. It is through the free flow of information that the multitude of subjective realities in turn can give rise to an objective reality when it is channelled through a transparent, open and legally coherent institutional framework, both locally and globally.

There is also the immense practical difficulty in determining beyond reasonable doubt and at a certain moment in time and space what constitutes a fact and what pertains to the world of fiction. As comprised in the oxymoron "virtual reality", the relationship between false and true, fact and fiction, seriousness and satire are more complex than a merely binary conception would be able to grasp. It is possibly for this reason that the 1953 Correction Convention found it impracticable "to institute, on the international level, a procedure for verifying the accuracy of a report which might lead to the imposition of penalties for the publication of false or distorted reports". However, the same statement also allows for the important conclusion that, if any such procedure is instituted, it must be at the global level. This argument has gained even further weight since then as the information technology revolution allows for the ubiquitous and instantaneous transmission of information from one placed to another. So far, however, a truly global media outlet is non-existent as different international news outlets, like BBC World, CNN, Al Jazeera, CGTN, TV5Monde all appear as "oxymora" as they are not "global" but "national media outlets", despite them operating transnationally but offering national, (i.e., British, US, Arabic, Chinese or French) perspectives of the world, but not "global news" per se.

Most importantly, however, it is the functioning of the human mind itself, which has realized so many outstanding achievements based on creativity made by two important factors, namely imagination and oxymoronic thinking, i.e., one which does not treat concepts carrying opposite meanings as mutually exclusive and conflicting. Together, fact and fiction hence function as a unique instrument of the human (and likely other species') brain, which is the ability to imagine any phenomenon and subsequently realize it. This is what Wittgenstein phrased by writing "what is thinkable is also possible" [132, p. 43], or what may have led homo sapiens to evolve to the point where "fiction" may now be the most potent force in the twenty-first century [46, p. 152]. It is also a tool that law should consider more in the context of forecasting the future by regulating it.

The law has more in common with science fiction that appears at first sight. The law has used its own fictions, termed "legal fiction" for a long time. This is another reason for why law is not the best tool to regulate "fake news", as it would open itself to the criticism that it treats certain information as true while knowing it to be false. The power of legal fictions is another reminder for the importance of the imaginary in the real world. It is also an important element in the consideration that the grammar of most languages and binary logic alone cannot do justice to the immense complexity of reality and of life.

In conclusion, and based on legal semiotics and legal synaesthesia, a broader and more integrated approach to law is needed. For fake news in particular, it is one which takes the multidimensional character of media into account and warrants a 
more comprehensive regulatory strategy to secure a reliable source of information provided by the news [29, pp. 5-6]. How such approach might look like in detail requires future research but, based on the existing state of the debate, it should use a more integrated and transdisciplinary method, including useful tools like legal semiotics and legal synaesthesia.

For such an integrated approach, it is advisable to strengthen the rule of law in all areas pertinent to information and, notably, also at the global level. The group of stakeholders included in the debate should also not only focus on the individual netizen but, equally, governments, political elites, and their intelligence services, multinational media corporations, social media platforms to mention but a few. Not least since the coining of the term "surveillance capitalism" and the Cambridge Analytica scandal and related data breach, it is known how data can and are being used across different sectors to manipulate the minds of masses to influence public opinion $[48,136]$. For fake news in particular, the areas of law considered should not only include the laws implementing the freedom of information [103], but also those on global trade law (and data flows) [15, 18], privacy and defamation laws [89], intellectual property laws [41], misleading advertising [94], and anti-trust/competition laws [50], as a way to guarantee media pluralism and a maximum reliability and diversity of content across all media.

In an age of greater concentration and complexity, as indicated by the term "predictive programming", possible conflicts of interest or illicit forms of collusion between a great variety of stakeholders, such as between public authorities, corporations, media conglomerates and wider entertainment industries should be thoroughly investigated. To this end, the conditions for an independent investigative journalism must be created and maintained. It should also take into account fake news at all levels of education, particularly in law and journalism [92, 102]. The legal debate must also align with new technologies, which-paradoxically—often pose both a threat and a cure for the ills associated with misinformation, such as AI's ability to be used to detect AI-generated fake content [112]. However, the aid of technological instruments must never replace adequate levels of human control and learning. In this regard, research must be conducted in cognitive (e.g., synaesthesia) and other means to enhance the human abilities to detect fake content and to "find ways to make sense of the paradoxes, to use them to shape a better destiny", as Charles Handy wrote [45, p. x]. In this regard, a global cognitive revolution of humanity is needed to keep track of the increasing complexity and amount of data processed every day. In the realm of law too, a similar cognitive and conceptual shift is needed if law wants to be able to "preserve its integrity over time, while managing to address the newly emerging circumstances that continually arise throughout our history" [56, p. 845]. The achievement of this goal may become more realistic using legal semiotics and legal synaesthesia to formulate a more integrated scientific theory and practice, allowing law to better reconcile the apparent contradictions underlying essentially oxymoronic concepts, such as those in frequently invoked oxymora like "fake news", "artificial intelligence", or "science fiction". Meanwhile, it is useful to consider that when in doubt as to whether information is fact or fiction, the actions taken based on them certainly will become facts eventually. 
Acknowledgements The author would like to thank Lilian Richieri Hanania, Vera Lúcia Raposo and Danny Friedmann for their useful comments on an earlier version of the article. The author gratefully acknowledges the financial support for a research project entitled "Law as 'Science Fiction': Future Regulatory Challenges from AI and other New Technologies" [MYRG2019-00017-FLL] provided by the University of Macau. Lastly, the author declares that there are no conflicts of interest.

\section{References}

1. Albrecht, Kristin Y. 2020. Fiktionen im Recht. Nomos Verlag.

2. Alemanno, Alberto. 2018. Editorial: How to counter fake news? A taxonomy of anti-fake news approaches. European Journal of Risk Regulation 9: 1-5.

3. Andersen, Kristian G., et al. 2020. The proximal origin of SARS-CoV-2. Nature Medicine. https://doi.org/10.1038/s41591-020-0820-9.

4. Ariely, Daniel. 2009. Predictably irrational: The hidden forces that shape our decisions. New York: HarperCollins.

5. Armentano, Dominick T. 1988. Is Antitrust Law an Oxymoron?. The Asian Wall Street Journal.

6. Baade, Björnstjern. 2019. Fake news and international law. The European Journal of International Law 29: 1357-1376.

7. Baden, Christian, and Tzlil Sharon. 2021. Blinded by the lies? Toward an integrated definition of conspiracy theories. Communication Theory 31: 82-106.

8. Bently, Lionel, and Leo Flynn, eds. 1996. Law and the senses: Sensational jurisprudence. London: Pluto Press.

9. Bertin, Paul, Kenzo Nera, and Sylvain Delouvée. 2020. Conspiracy beliefs, rejection of vaccination, and support for hydroxychloroquine: A conceptual replication-extension in the COVID19 pandemic context. Frontiers of Psychology. https://doi.org/10.3389/fpsyg.2020.565128.

10. Biggs, Michael. 2013. Prophecy, self-fulfilling/self-defeating. In Encyclopedia of philosophy and the social sciences, ed. Byron Kaldis, 765-766. Los Angeles: Sage.

11. Bijker, Wiebe E., Roland Bal, and Ruud Hendriks. 2009. Paradox of scientific authority: The role of scientific advice in democracies. Cambridge: MIT Press.

12. Bork, Robert H. 1978. The Antitrust Paradox: A Policy at War With Itself. New York: The Free Press.

13. Bottici, Chiara, and Benoit Challand. 2006. Rethinking political myth: The clash of civilizations as a self-fulfilling prophecy. European Journal of Social Theory 9: 315-336.

14. Broekman, Jan M., and Frank Fleerackers. 2020. Legal thoughts convert: Rethinking legal thinking. Cham: Springer.

15. Burri, Mira, ed. 2021. Big data and global trade law. Cambridge: Cambridge University Press.

16. Burroughs, William S.. 1980. In Gordon, Mel. 1980. Laurie Anderson's 'United States Part II.' The Drama Review 24: 112-115.

17. Cheng, Vincent C.C.., et al. 2007. Severe acute respiratory syndrome coronavirus as an agent of emerging and reemerging infection. Clinical Microbiology Reviews 20: 660-694.

18. Ciuriak, Dan. 2019. World Trade Organization 2.0: Reforming multilateral trade rules for the digital age. Center for International Governance Innovation Policy Brief No. 152. https://www. cigionline.org/publications/world-trade-organization-20-reforming-multilateral-trade-rulesdigital-age.

19. Coleman, Loren. 2004. The copycat effect: How the media and popular culture trigger the mayhem in tomorrow's headlines. New York: Paraview Pocket Books.

20. Cover, Robert M. 1983. The supreme court, 1982 term: Foreword: Nomos and narrative. Harvard Law Review 97: 4-68.

21. Csicsery-Ronay, Istvan. 2008. The seven beauties of science fiction. Middletown: Wesleyan University Press.

22. Cytowic, Richard E. 2002. Synesthesia: A union of the senses, 2nd ed. Cambridge: MIT Press.

23. DeChardin, PierreTeilhard. 1978. Activation of energy. San Diego: A Harvest Book.

24. Dentith, Matthew R.X.. 2014. The philosophy of conspiracy theories. New York: Palgrave Macmillan. 
25. Deroy, Ophelia, and Charles Spence. 2013. Are We All Born Synaesthetic? Examining the Neonatal Synaesthesia Hypothesis. Neuroscience and Biobehavioral Reviews 27: 1240-1253.

26. Diaconis, Persi, and Frederick Mosteller. 1989. Methods for Studying Coincidences. Journal of the American Statistical Association 84: 853-861.

27. Eisenberger, Iris. 2016. Innovation im recht. Vienna: Verlag Österreich.

28. Ermida, Isabel. 2012. News satire in the press: Linguistic construction of humour in spoof news articles. In Language and humour in the media, ed. Jan Chovanec and Isabel Ermida, 185-210. Newcastle upon Tyne: Cambridge Scholars.

29. Commission, European. 2018. A multi-dimensional approach to disinformation (report of the independent high level group on fake news and online disinformation. Luxemburg: Publications Office of the European Union.

30. Fletcher, George P. 1985. Paradoxes in legal thought. Columbia Law Review 85: 1263-1292.

31. Foucart, Stéphane. 2021. Pandémie de Covid-19: le virus circulait sans doute en France dès novembre 2019. Le Monde (10 February 2021). https://www.lemonde.fr/planete/article/2021/02/ 10/le-sars-cov-2-circulait-sans-doute-en-france-des-novembre-2019_6069431_3244.html.

32. Fuller, Lon L. 1930. Legal fictions. Illinois Law Review 25: 363-399.

33. Funke, Daniel and Daniela Flamini. 2021. A guide to anti-misinformation actions around the world. Poynter. https://www.poynter.org/ifcn/anti-misinformation-actions/.

34. G20. 2020. Extraordinary G20 leaders' summit statement on COVID-19. https://g20. gov.sa/en/media/Documents/G20_Extraordinary\%20G20\%20Leaders\%E2\%80\%99\%20 Summit_Statement_EN\%20(3).pdf.

35. Gallie, Walter B. 1956. Essentially contested concepts. Proceedings of the Aristotelian Society 56 : 167-198.

36. Gates, Bill. 2015. The next outbreak? We are not ready. Ted Talk (4 April 2015). https://www. youtube.com/watch?v=6Af6b_wyiwI.

37. Gidley, Jennifer. 2017. The future: A very short introduction. Oxford: Oxford University Press.

38. Gitelman, Lisa, and Virginia Jackson. 2013. Introduction. In "Raw data” is an oxymoron, ed. Lisa Gitelman, 1-14. Cambridge: MIT Press.

39. Gladwell, Malcolm. 2005. Blink: The power of thinking without thinking. New York: Back Bay.

40. Gleick, James. 2000. Faster: The acceleration of just about everything. New York: Vintage Books.

41. Goodyear, Michael. 2020. Is there no way to the truth? Copyright liability as a model for restricting fake news. Harvard Journal of Law \& Technology 34: 279-306.

42. Goscinny, René, and Albert Uderzo. 2018. Asterix and the Chariot Race. London: Orion.

43. Groh, Matthew et al. 2020. Human detection of machine manipulated media. arXiv:1907.05276. https://arxiv.org/pdf/1907.05276.pdf.

44. Halpern, Daniel et al. 2019. From belief in conspiracy theories to trust in others: Which factors influence exposure, believing and sharing fake news. In Social computing and social media. Design, human behavior and analytics, ed. Gabriele Meiselwitz, 217-232. Cham: Springer.

45. Handy, Charles. 1995. The age of paradox. Boston: Harvard Business School Press.

46. Harari, Yuval N. 2017. Homo deus: A brief history of tomorrow. New York: Harper Collins.

47. Hawkes, Terence. 2003. Structuralism and semiotics. London: Routledge.

48. Heawood, Jonathan. 2018. Pseudo-public political speech: Democratic implications of the Cambridge Analytica scandal. Information Polity 23: 429-434.

49. Held, David. 2010. Cosmopolitanism: Ideals and realities. Cambridge: Polity Press.

50. Hubbard, Sally. 2017. Fake news is a real antitrust problem. Competition Policy International (19 December 2017). https://www.competitionpolicyinternational.com/fake-news-is-a-real-antitrustproblem/.

51. Huff, Darrell. 1954. How to lie with statistics. New York: W.W. Norton.

52. Huntington, Samuel P. 1993. The clash of civilizations. Foreign Affairs 72: 22-49.

53. International Law Commission (ILC). 2006. Fragmentation of International Law: Difficulties Arising from the Diversification and Expansion of International Law. A/CN.4/L.682.

54. Ireton, Cherilyn, and Julie Posetti. 2018. Journalism, fake news \& disinformation: Handbook for journalism education and training. Paris: UNESCO.

55. Nie, Jing-Bao. 2020. In the shadow of biological warfare: Conspiracy theories on the origins of COVID-19 and enhancing global governance of biosafety as a matter of urgency. Bioethical Inquiry 17: 567-574.

56. Johnson, Mark L. 2007. Mind, metaphor, law. Mercer Law Review 58: 845-868. 
57. Kapur, Narinder, et al. 2011. The paradoxical nature of nature. In The paradoxical brain, ed. Narinder Kapur, 1-13. Cambridge: Cambridge University Press.

58. Kaur, Harmeet. 2020. No, Dean Koontz did not predict the coronavirus in a 1981 novel. CNN (13 March 2020). https:/edition.cnn.com/2020/03/13/us/dean-koontz-novel-coronavirus-debunk-trnd/ index.html.

59. Koontz, Dean. 1996. The eyes of darkness. New York: Berkeley Books.

60. Lang Andrew, T.F. 2007. Reflecting on 'linkage': Cognitive and institutional change in the international trading system. Modern Law Review 70: 523-549.

61. Laszlo, Ervin. 2004. Science and the akashic field: An integral theory of everything, 2nd ed. Rochester: Inner Traditions.

62. LeCarré, John. 2001. The constant gardener. New York: Scribner.

63. Lee, Terry. 2019. The global rise of "fake news" and the threat to democratic elections in the USA. Public Administration and Policy 22: 15-24.

64. Lehrer, Jonah. 2009. How we decide. Boston: Houghton Mifflin Harcourt.

65. Lessing Garrett, Gregory. 2020. Stand or fall in the covid 19 chess game. Hollister: Gregory L. Garrett.

66. Levi, Lili. 2017. Real Fake News and Fake Fake News. First Amendment Law Review 16: 232-327.

67. Lewis, Gilbert N. 1926. Anatomy of science. New Haven: Yale University Press.

68. Luhmann, Niklas. 2000. The reality of mass media. Stanford: Stanford University Press.

69. Martínez, Alberto A. 2018. Burned alive: Giordano Bruno, Galileo and the inquisition. London: Reaktion Books.

70. Marusek, Sarah, ed. 2017. Synesthetic legalities: Sensory dimensions of law and jurisprudence. Oxon: Routledge.

71. May, Andrew. 2020. Pseudoscience and science fiction. Cham: Springer.

72. McComiskey, Bruce. 2017. Post-truth rhetoric and composition. Logan: Utah State University Press.

73. McGurk, Harry, and John MacDonald. 1976. Hearing lips and seeing voices. Nature 264: 746-748.

74. McLuhan, Marshall. 1989. In Marshall McLuhan: The man and his message, eds. George Sanderson and Frank MacDonald, 64. Golden: Fulcrum.

75. McLuhan, Marshall. 1994. Understanding media: The extensions of man. Cambridge: The MIT Press.

76. Mehra, Mandeep R. et al. 2020. Retraction-Hydroxychloroquine or chloroquine with or without a macrolide for treatment of COVID-19: A multinational registry analysis. The Lancet. https://doi. org/10.1016/S0140-6736(20)31180-6.

77. Merleau-Ponty, Maurice. 1962. Phenomenology of Perception. Routledge \& Keagan Paul London.

78. Merton, Robert K. 1948. The self-fulfilling prophecy. The Antioch Review 8: 193-210.

79. Mheidly, Nour, et al. 2020. Effect of face masks on interpersonal communication during the COVID-19 pandemic. Frontiers in Public Health 8: 1-6.

80. Miller, Joanne M. 2020. Psychological, political, and situational factors combine to boost COVID19 conspiracy theory beliefs. Canadian Journal of Political Science 53: 327-334.

81. Molter, Vanessa and Graham Webster. 2020. Virality project (China): Coronavirus conspiracy claims. Freeman Spogli Institute for International Studies (FSI). https://fsi.stanford.edu/news/ china-covid19-origin-narrative.

82. Neuwirth, Rostam J. 2006. 'United in divergency': A commentary on the UNESCO convention on the protection and promotion of the diversity of cultural expressions. Zeitschrift für ausländisches öffentliches Recht und Völkerrecht 66: 819-862.

83. Neuwirth, Rostam J. 2013. Essentially oxymoronic concepts. Global Journal of Comparative Law 2: $147-166$.

84. Neuwirth, Rostam J. 2018. Law in the time of oxymora: A synaesthesia of language, logic and law. New York: Routledge.

85. Neuwirth, Rostam J. 2019. Law, time and oxymora: A synaesthetic exploration of the future role of customary global law. Revista General de Derecho Público Comparado 26: 1-29.

86. Neuwirth, Rostam J. 2020. The 'letter' and 'spirit' of comparative law in the time of 'artificial intelligence' and other oxymora. Canterbury Law Review 26: 1-31.

87. Neuwirth, Rostam J. 2020b. GAIA 2048-A 'glocal agency in anthropocene': Cognitive and institutional change as 'legal science fiction'. In A post-WTO international legal order: Utopian, 
dystopian and other scenarios, eds. Meredith Kolsky Lewis, Junji Nakagawa, Rostam J. Neuwirth, Colin B. Picker and Peter-Tobias Stoll, 71-92. Cham: Springer.

88. Newton, Michael. 2006. The encyclopedia of conspiracies and conspiracy theories. New York: Facts On File.

89. Nice, Randall D. 2019. Reviving the lost tort of defamation: A proposal to stem the flow of fake news. Arizona Law Review 61: 205-230.

90. Orwell, George. 1949. Nineteen Eighty Four. Reprinted in George Orwell, Complete Works, 791925. London: Martin Secker \& Warburg.

91. Orzechowski, Marcin, Maximilian Schochow, and Florian Steger. 2021. Balancing public health and civil liberties in times of pandemic. Journal of Public Health Policy. https://doi.org/10.1057/ s41271-020-00261-y.

92. Pearson, Mark. 2017. Teaching media law in a post-truth context: Strategies for enhancing learning about the legal risks of fake news and alternative facts. Asia Pacific Media Educator 27: 17-26.

93. Petoft, Arian, and Mahmoud Abbasi. 2019. A historical overview of law and neuroscience: From the emergence of medico-legal discourses to developed neurolaw. Journal on European History of Law 10: 15-33.

94. Petty, Ross D. 1996. The law of misleading advertising: An examination of the difference between common and civil law countries. International Journal of Advertising 15: 33-47.

95. Pinsky, William W. 2001. Academic affairs: The constant gardener. Ochsner Journal 3: 186.

96. Popper, Karl R. 1947. The open society and its enemies: The spell of Plato, vol. 1, 1947. London: Routledge.

97. Posetti, Julie, and Alice Matthews. 2018. A short guide to the history of 'fake news' and disinformation: A learning module for journalists and journalism educators. Washington: International Center for Journalists.

98. Pradhan, Prashant et al. 2020. Uncanny similarity of unique inserts in the 2019-nCoV spike protein to HIV-1 gp120 and gag. bioRxiv. https://doi.org/10.1101/2020.01.30.927871.

99. Quinn, Adrian. 2001. Tout est lié: The Front National and media conspiracy theories. The Sociological Review 48: 112-132.

100. Raposo, Vera Lúcia. 2020. Quarantines: Between precaution and necessity. A look at COVID-19. Public Health Ethics. https://doi.org/10.1093/phe/phaa037.

101. Respers France, Lisa. 2020. Another example of 'the Simpsons' predicting future. CNN (8 May 2020). https://edition.cnn.com/2020/05/08/entertainment/simpsons-coronavirus-insects-predi ctions/index.html.

102. Richardson, Nick. 2017. Fake news and journalism education. Asia Pacific Media Educator 27: $1-9$.

103. Richter, Andrei. 2018. Fake news and freedom of the media. Journal of International Media and Entertainment Law 8: 1-34.

104. Robertson, Lynn C., and Noam Sagiv, eds. 2005. Synesthesia: Perspectives from cognitive neuroscience. Oxford: Oxford University Press.

105. Robertson, Morgan. 1898. The wreck of the titan: Or, futility. Rahway: The Quinn and Boden Press.

106. Rose, Jonathan. 2017. Brexit, Trump, and post-truth politics. Public Integrity 19: 555-558.

107. Rosenau, James N. 1995. Governance in the 21st century. Global Governance 1: 13-43.

108. Rothkopf, David J. 1999. The disinformation age. Foreign Policy 114: 82-96.

109. Rovelli, Carlo. 2018. The order of time. New York: Riverhead Books.

110. Sciortino, Antonella. 2020. Fake news and infodemia at the time of covid-19. Revista Direito Público 17: 35-49.

111. Sigismondi, Paolo. 2012. The digital glocalization of entertainment: New paradigms in the 21st century global mediascape. New York: Springer.

112. Singh, Saurabh et al. 2020. A statistical analysis of various technologies to detect and prevent fake news. In Data science and analytics, eds. Usha Batra, Nihar Ranjan Roy and Brajendra Panda, 164-172. Singapore: Springer Nature.

113. Singleton, Stephanie L. 2008. According to rumor, It's a conspiracy: Conspiracy theory as a paradigmatic construct. Bloomington: Indiana University, Dept. of Folklore and Ethnomusicology.

114. Stewart, William J. 1988. Stimulating intuitive thinking through problem solving. The Clearing House 62: 175-176.

115. Sunstein, Cass R. 2014. Conspiracy theories and other dangerous ideas. New York: Simon Schuster. 
116. Surette, Ray. 2013. Pathways to copycat crime. In Criminal psychology: Typologies, mental disorders, and profiles, vol. 2, ed. Jacqueline B. Helfgott, 251-273. Santa Barbara: Praeger.

117. TandocJr, EdsonC., Zheng Wei Lim, and Richard Ling. 2018. Defining "fake news." Digital Journalism 6: 137-153.

118. Tauber, Alfred I. 1997. Introduction. In Science and the quest for reality, ed. Alfred I. Tauber, 1-49. Houndmills: Macmillan.

119. Thaler, Richard H., and Cass R. Sunstein. 2008. Nudge: Improving decisions about health, wealth, and happiness. New Haven: Yale University Press.

120. The Johns Hopkins Center for Health Security. 2019. Event 201-A global pandemic exercise. https://www.centerforhealthsecurity.org/event201/.

121. The Johns Hopkins Center for Health Security. 2019. Statement about nCoV and our pandemic exercise. https://www.centerforhealthsecurity.org/news/center-news/2020/2020-01-24-Statementof-Clarification-Event201.html.

122. The Johns Hopkins Center for Health Security. 2019. The event 201 scenario. https://www.centerforhealthsecurity.org/event201/scenario.html.

123. VonBülow, Oskar. 1879. Civilprozessualische fiktionen und wahrheiten. Archiv für die civilistische Praxis 62: 1-96.

124. Wade, Nicholas J. 2005. Perception and Illusion: Historical Perspectives. Dordrecht: Springer.

125. Wagner, Anne, Aleksandra Matulewska and Sarah Marusek. 2021. Pandemica panoptica: Biopolitical management of viral spread in the age of covid-19. International Journal for the Semiotics of Law. https://doi.org/10.1007/s11196-021-09821-1.

126. Wagner, Anne. 2010. Mapping legal semiotics. International Journal for the Semiotics of Law 23: 77-82.

127. Weimann, Gabriel. 2000. Communicating unreality: Modern media and the reconstruction of reality. London: SAGE.

128. Weisberg, Richard H. 1992. Poethics, and other strategies of law and literature. New York: Columbia University Press.

129. Weiss, Alan, and Chad Bar. 2012. Million dollar web presence: Leverage the web to build your brand and transform your business. Irvine: Entrepreneur Press.

130. Whitehead, Kate. 2020. China wasn't original villain in book 'predicting' coronavirus outbreak - it was Russia. South China Morning Post (20 March 2020). https://www.scmp.com/lifestyle/artsculture/article/3051619/china-wasnt-original-villain-book-predicting-coronavirus.

131. Winter, Amy Elise. 2021. The impact of the world military games on the COVID-19 pandemic. Irish Journal of Medical Science. https://doi.org/10.1007/s11845-020-02484-0.

132. Wittgenstein, Ludwig. 1960. Tractatus logico-philosophicus. London: Routledge.

133. World Health Organization (WHO) 2020. Archived: WHO timeline-COVID-19. https://www. who.int/news/item/27-04-2020-who-timeline---covid-19/.

134. Yale, Leroy M. 1888. Babyhood: A monthly magazine for mothers, vol. IV. London: Babyhood.

135. Yang, Xin, Yuezun Li and Siwei Lyu. 2020. Exposing deep fakes using inconsistent head poses. arXiv:1811.00661. https://arxiv.org/pdf/1811.00661.pdf.

136. Zuboff, Shoshana. 2018. The age of surveillance capitalism: The fight for a human future at the new frontier of power. New York: Public Affairs.

Publisher's Note Springer Nature remains neutral with regard to jurisdictional claims in published maps and institutional affiliations. 